\title{
ORIGENS DO DIREITO DA CONCORRÊNCIA
}

\author{
Luiz Olavo Baptista \\ Professor Titular do Departamento de Direito Internacional da \\ Faculdade de Direito da Universidade de São Paulo
}

Resumo:

A expressão inglesa "fair play" resume, em primeiro plano, os fundamentos e a origem da legislação da concorrência - que visa assegurar um caráter de lealdade à competição no mercado.

Em segundo plano, o porquê da existência do direito da concorrência é justificado pela necessidade de regulamentação das imperfeições do mercado que pela suas limitações (como custos que, em tese, não seriam pagos por ninguém e a possibilidade de formação de monopólios) - não consegue regular-se somente pelo equilíbrio entre ofertas e demandas.

Atualmente, a concorrência desleal ao revés de outrora - é vista sob o prisma da defesa dos interesses da sociedade, em especial do consumidor, e, neste contexto, destaca-se o CADE (órgão instituído pela Lei n. 4.137/62) que vem impedindo que se estabeleçam monopólios ou outras formas de concorrênca desleal em nossa economia.

Abstract:

The english expression "fair play" summarizes, foreground, the basis and the origin of the antitrust legislation. This expression intends to safeguard the loyalty towards market competition.

Secondly, the existence of antitrust legislation can be justified by the regulation necessity of the market's imperfections, since the market's limitations (as costs that, in thesis, wouldn't be payed, and the possibility of the monopoly formation) can't adjust itself, only by supply and demand equilibrium.

Nowadays, the unfair competition, differently from before, is focused under the society interests' defense and specially consumer's interests, in this context, a rises CADE, a body that exercises its activity fighting against the establishment of monopolies and other forms of antitrust in our economy.

Unitermos: legislação da concorrência - concorrência desleal 
O curso das políticas na História da Humanidade não é linear, mas, sim, senoidal, como que refletindo os movimentos de um pêndulo ao longo da evolução. Às idéias descentralizadoras, como o feudalismo, seguem-se as centralizadoras, como o absolutismo, às estatizantes, sucedem-se as liberais e viceversa. Nesse incessante vai-e-vem, as distâncias entre um e outro extremo ficam menores, pois sempre algo da ideologia anterior ficou integrado à realidade política.

$\mathrm{O}$ Brasil não foge à regra. Do excessivo estatismo que a visão militar impôs ao Estado nos anos em que predominou, e em que, apesar do discurso contrário, o liberalismo praticamente desapareceu, substituído por uma política neomercantilista e centralizadora, incentivadora de monopólios, chega-se agora à maré desestatizante, liberal, inimiga dos monopólios.

Mas é fato que o monopólio é conseqüência do capitalismo sem peias, como a ditadura soviética o foi da visão Ieninista do socialismo, ambos tendentes a sufocar as liberdades humanas.

Assim, o ideal da preservação da liberdade de competição, pela repressão dos monopólios, gerou, nos EUA, no fim do século passado, mais precisamente em 2 de julho de 1890, a edição do Shermann Act, norma que criou o modelo do chamado direito anti-trust.

Ao mesmo tempo, subsistem mecanismos de controle da economia pelo Estado, consistentes na repressão a certas condutas que configuram o abuso ao direito de agir na economia, à liberdade de iniciativa, tais como as restrições decorrentes do poder de polícia.

Estas regras, por sua vez, haviam sucedido ao direito das corporações, conforme veremos mais adiante, neste apanhado histórico.

Todas têm em comum o fato de que abordaram o fenômeno econômico da concorrência, da competição econômica pelo mercado, e sobretudo no dizer de Menendez
"de algo aún más concreto, la significación juridica de uno de los males que puede padecer esa competencia, una situación patologica que para seguir manteniendo la terminologia classica classificaríamos como la enfermidad de la deslealdad"1 
Para recordar essa trajetória começaremos pelo que ocorreu em outros países, cujo desenvolvimento econômico induziu o pioneirismo na legislação concorrencial, para depois chegar à evolução em direito brasileiro. Este roteiro permitirá, também, alcançar uma visão comparativa.

I Origem e fundamentos da legislação concorrencial

Um grande comercialista espanhol, o Professor Garriguez, lembrava em sua obra sobre a matéria ${ }^{2}$ que a competição extravasa a economia e permeia o esporte, a ciência, e até mesmo o amor, acrescentando, com certa ironia que esta última

\section{"es quizá la más dramática y aguda de todas las competencias, pues se trata de la lucha por una sola mujer, que no es fungible o sostituible por otra, como ocurre con los clientes en la lucha de los competidores mercantiles"}

O fato é que presente em várias facetas da vida humana, o direito tem se preocupado, neste século, em regular esse fenômeno de natureza complexa e pluridimensional, a competição, para assegurar-lhe um caráter de lealdade, ou na expressão inglesa, fair play o que levou a diversos enfoques e enquadramentos jurídicos.

Entretanto, no campo da atividade econômica temos visto uma coerência evolutiva, e a tônica colocada na idéia de liberdade de concorrência.

Uma precisão se faz necessária, do ponto de vista histórico: o direito da concorrência tal como o conhecemos hoje não é o mesmo de suas origens.

Ele tem sofrido mutações qualitativas importantes, ligadas às dos meios de produção, e tão-relevantes, que nos podem levar, até mesmo, a supor que se trata de novos ramos do direito que foram criados. É bem verdade que esse fenômeno das mutações ocorre em muitos outros ramos do direito, e sua característica é a criação de novos modelos, muitas vezes sobrepostos aos antigos, que ampliam e modificam, como os templos dos astecas, construídos sobre os dos toltecas e os destes sobre os dos seus antecessores. Outras vezes, ocorre das 
instituições e regras antigas permanecerem atrofiadas, pela diminuição da importância relativa dos fenômenos econômicos a que se referiam, enquanto ao lado vicejam as novas, que respondem a realidades mais vigorosas e atuais. Vamos encontrar ambos os caminhos na regulamentação da concorrência.

O liberalismo cuja influência continua presente em nossos dias sustentava uma visão utópica, a da liberdade de competição, que nunca passou de um modelo teórico econômico-filosófico. A realidade como a teoria econômica apontou é a da concorrência imperfeita, limitada pelas próprias deficiências dos mecanismos do mercado, tais como a heterogeneidade ou falta de homogeneidade dos bens, pela existência de interferências dos que podem afetar o mercado (atores mais poderosos, inclusive o Estado), e pelo próprio ordenamento jurídico. Não é o caso de examinar os fatores de ordem econômica, ou os aspectos da teoria econômica, que serão contemplados em outro lugar.

O fato é que, há limites para a liberdade de mercado, e na ordem jurídica, estes contêm os que a legislação impõe, visando preservar, na área que não toca, a concorrência. Ora, isto quer dizer simplesmente que determinadas práticas são reprimidas, pois se julgam serem danosas para a concorrência - por exemplo proíbem-se os acordos anticoncorrenciais, as colusões, as práticas abusivas fundadas numa posição dominante.

Ao fazer o exame arqueológico do direito da concorrência encontramos, na camada superior o que se chama usualmente de direito antitruste, e abaixo, nas fundações deste, a repressão à concorrência desleal. Esta visa o fenômeno da deslealdade sob o prisma individual, aquele sob a óptica social. Uma refere-se ao dano que a conduta ilícita acarreta diretamente à vítima, a outra endereça-se - em geral sem ignorar a sorte do concorrente atingido - às práticas que tendem ou alcançam a idéia de concorrência mesma e a estrutura do mercado.

O que une estas abordagens é a idéia de que a noção de competição é uma só, e que ela só se justifica economicamente com base no princípio da eficiência, e que do ponto de vista jurídico os interesses tutelados são os mesmos, porém em círculos concêntricos cada vez maiores: a proteção do competidor direto, e a de todos os participantes do mercado, - competidores (produtores, comerciantes, prestadores de serviços etc.) e consumidores, - do interesse coletivo, na conservação do mercado.

Como se sabe, o liberalismo econômico nunca chegou a ser a teoria dominante no Brasil, apesar dos discursos abundantes contra e a favor do mesmo, 
nem chegou a seguir aqui o curso de sua evolução completa, tendo sempre predominado, isso sim, e ainda que travestido de liberalismo, o mercantilismo ibérico e o neo-mercantilismo. Este deitou raízes durante a época colonial, reviveu sob o protecionismo do fim do século 19 e primeiro quartel deste, e sobreviveu desde os tempos coloniais.

Por isso, o direito antitruste nunca atingiu seu pleno desenvolvimento entre nós. É na Espanha como Portugal uma das pátrias dessa versão patrimonialista e burocrática do mercantilismo que vamos encontrar um paralelismo histórico, na evolução econômica e jurídica nesse campo.

No Brasil, como na Espanha, até há pouco, a legislação concorrencial era dispersa, lacunosa, fazendo-lhe falta uma sistemática processual adequada, além de ter sido menosprezada pela doutrina. ${ }^{3}$ Lá o direito da concorrência chegou tardio, como o capitalismo liberal; aqui, o mesmo acontece, com a diferença de que o capitalismo liberal chega em determinadas partes do país, enquanto em outras ainda subsiste a estrutura mais arcaica com as formas menos desenvolvidas da economia. Isso leva a que certas normas de efeitos hoje marginais na Espanha, aqui, ainda se revistam de importância maior.

À regulamentação corporativa - e portanto regulamentação da concorrência - passou-se à repressão à concorrência desleal - como mecanismo de proteção do direito de propriedade para, depois, pela generalização das regras, chegar-se, finalmente, ao direito anti-trust.

\section{A concorrência desleal}

Os modelos de regulamentação da competição desleal são vinculados ao chamado sistema econômico liberal. ${ }^{4}$

Até o advento deste, na época em que imperava o mercantilismo, as corporações mantinham um importante papel, e por essa razão falar em direito da competição não tinha cabimento. Na realidade, existiam regras de concorrência, mas não sobre a concorrência, pois as atividades econômicas eram regulamentadas pelas

3. A este propósito, basta ver como é pobre a bibliografia na matéria, no Brasil.

4. Conferir Franceschelli, Trattato di diritto industriale, Milano, 1960, I, p. 393 e ss; Ghidini, G. Slealtà della concorenza e constituzione economica, Padova, 1978, p. 14 e ss. 
corporações que delas detinham o monopólio, e, depois, pelo estado absolutista.

Sob certo ângulo, pode-se, ainda, imaginar coincidências parciais entre a disciplina da competição desleal que se desenvolve e as regras anteriores. Entretanto, encarando o fenômeno de modo global, verifica-se que tanto no plano funcional quanto no qualitativo, elas são diversas. Os dois fenômenos normativos, a regulamentação da atividade profissional na época das corporações e na do mercantilismo, e o direito da concorrência, correspondem a atividades econômicas situadas cada qual em um plano histórico diferente, e num plano econômico diverso.

Assim, nos convém ignorar, aqui, a regulamentação de natureza corporativa ainda que no sistema brasileiro a mesma persista, como no caso de advogados, médicos, engenheiros, contadores, secretárias, bibliotecárias e muitas outras profissões para tratarmos do direito da competência, que é a disciplina moderna e que impera no mundo.

Esta se vincula de início à idéia de que a economia deveria reger-se pelo princípio da liberdade de indústria e comércio. É, entretanto, evidente que esse princípio, da liberdade de indústria e comércio, colocado em termos extremos no início do liberalismo, sofre uma transformação que acompanha as mudanças econômica, política e constitucional do mundo ocidental. Ocorre também o reconhecimento por parte da doutrina da inexistência da concorrência perfeita, e a necessidade de regulamentar as conseqüências dessa imperfeição. De qualquer modo, temos uma evolução histórica marcada pela diferença no interesse econômico tutelado.

Um autor, Aurélio Menendez, ${ }^{5}$ propõe três modelos, a que chama o primeiro, de paleo liberal, o qual era o imperante no início do século XIX, o segundo de profissional, o qual começa no início deste século, e o último, o denomina de modelo social, com início no término da Segunda Guerra Mundial, e que representa uma mudança qualitativa em relação aos modelos anteriores.

$\mathrm{O}$ modelo paleo liberal caracteriza-se pela falta de uma normativa geral. A disciplina da competência nele, resulta, segundo esse autor, muito fragmentada e contempla somente determinadas violações dos direitos da propriedade industrial. 
Entretanto, face ao impulso econômico, pouco a pouco vão se acrescendo novas regras e estas vão formando um novo corpo, que vem a ser o modelo profissional.

Este tem um caráter privado na sua normatização, embora o seu alcance seja geral.

Quer-se tutelar, de acordo com padrões de valorização profissional da classe empresarial, as posições que uma empresa adquiriu no mercado. Trata-se de um modelo que tem caráter monopolista. Aliás, tanto o modelo paleo liberal quanto este, por se fundarem na idéia de que a competição estava vinculada à propriedade industrial, tem este caráter monopolista.

É com o Shermann Act nos Estados Unidos, e depois, com normas parecidas, em outros países ao fim da Segunda Guerra Mundial, por influência norteamericana, que ocorre a mudança de rumo. Ou melhor, que há o marco dessa mudança.

Esta se caracteriza, como a anterior, fundamentalmente, pela troca de óptica e de valor protegido. Deixa-se de encarar a proteção do interesse da empresa, meta do modelo profissional, para encarar a proteção do interesse da sociedade, e, através dela, do consumidor. É a tutela do interesse dos consumidores, do interesse público genérico na manutenção de uma ordem concorrencial adequada, que vem caracterizar esta nova situação.

Vejamos a caracterização destes modelos um por um.

O modelo paleo liberal

O modelo paleo liberal de competição desleal está vinculado ao início da era industrial, e a sua característica, é a visão liberal clássica, isto é, a liberdade absoluta de indústria e comércio. Sucede aos regulamentos de atividades econômicas do mercantilismo, cujo fito era o de proteger os atores limitando ou impedindo a concorrência, interna ou internacional.

No modelo paleo liberal, admite-se que qualquer iniciativa seria legítima desde que ela não implicasse na violação de um direito da propriedade de alguém, ou não se violassem as normas penais, repressivas das fraudes mais graves. ${ }^{6}$ A expressão fundamental aí é fraude, a palavra-chave é dolo.

6. Veja-se a propósito Galgano, Trattato di Diritto Commerciale e de Diritto Pubblico dell'Economia, v. 3, Padova, 1979, p. 374 e ss. 
É de se lembrar, para bem entender essas regras, o pensamento de Jean Baptiste Say. ${ }^{7}$ Este autor dizia que a intervenção do Estado nos processos concorrenciais só poderia justificar-se com o fim de evitar o engano no mercado (portanto as condutas dolosas), mas que, mesmo assim, não era desejável, pois, ao termo e ao fim, acabaria por prejudicar o tráfico econômico na sua generalidade.

Tratando-se de uma exceção à liberdade, as regras de concorrência tinham caráter proibitivo e se tratavam, por isso, de leis especiais. Pode-se dizer que a proteção era feita predominantemente pela via penal, e portanto só alcançava aqueles tipos que estavam descritos na lei penal, e era essa a única via.

Era normal, por isso, que a proteção se construísse de maneira fragmentária, isto é, a prática de um fato nocivo, (que depois iria ser definido como delito) é que gerava a necessidade de uma regra de proteção. Não se via, como hoje, o caráter genérico das condutas concorrenciais. Deve-se ver que na maioria dos países, em consequiência disso, a disciplina da competição desleal se desenvolveu, então, sobre esta tutela da propriedade dos bens imateriais ou de monopólios legais, ou seja, na proteção sobretudo das marcas e depois também das patentes. Esta proteção das marcas e das patentes, num contexto penal e de alta tipicidade constituem aquilo que o autor já citado (Menendez) dizia ser "um precipitado necessário dessa concepção inicial do ato de competição desleal, como uma lesão de direito de propriedade industrial". ${ }^{8}$

Em conseqüência dessas teorias, a disciplina da concorrência é vista como proteção da propriedade, portanto o objeto aí é a propriedade, a tutela dos direitos sobre os bens imateriais ou de monopólio, em especial a marca. ${ }^{9}$

Também seria conveniente, para entender o modelo paleo liberal, levar em conta as necessidades da indústria, que então estava no seu nascedouro. Esta precisava de um certo campo livre para proceder a imitações e modalidades enganosas, como apontou Ramella. ${ }^{10}$

7. Traité de économie, politique, v. I, Bruxelas, 1827, p. 186 e ss.

8. Ob. cit., p. 33 .

9. Cf. Pouillet, Traité des marques de fabrique et de la concurrence déloyale, Paris, 1898, p. VIII V. também Jaeger "Valutazione comparativa degli interessi e concorrenza sleale", Riv. Dir. Ind., 1970, p. 37; Le Moal, Droit de Concurrence, Paris, 1979, p. 163 e ss.; Callman, The Law of Unfair Competition, Trademarks and Monopolies, I, Mundelein, Dinois, 1967, p. 108 e ss.

10. Tratado de la Propriedad Industrial, Madrid, 1913, trad., p. 301. 
A ausência de freios estatais, era vista como uma condição para a decolagem econômica e de existência do próximo sistema. ${ }^{11}$

Uma vez consolidada a indústria, o suficiente para que não temesse a intervenção estatal em defesa de posições adquiridas no mercado, os próprios grupos empresariais mais fortes começaram a pressionar pela criação de uma disciplina da competição, que teve origem, em primeiro lugar, pela ação da jurisprudência. Aí, as empresas recorriam a autotutela defendendo-se das iniciativas desleais dos seus competidores.

Nesse caso, a criação de trustes e cartéis e acordos defensivos surgiu como uma conseqüência natural da economia competitiva, vista então sob uma óptica spengleriana de sobrevivência do mais forte ou apto. É este o modelo da maioria dos ordenamentos europeus durante o século XIX, e também daquele dos Estados Unidos.

O primeiro exemplo significativo de normas contra a concorrência desleal, que invocamos, é a experiência da Alemanha.

Em 1869, o tribunal (o Reichsgericht) dizia que todo o comportamento concorrencial que não fosse expressamente proibido pela lei, era admissível, proclamando o Gewerbefreiheit, ou seja, o princípio da liberdade de indústria e comércio.

Assim, era ilícita apenas a atividade como tal prevista: por exemplo na Markenschutzgesetz de 30.11.1874, que proibia, no âmbito penal e de modo muito restrito, determinadas práticas, como as falsas denominações de origem, ou a violação do uso de sinais distintivos.

A primeira ordenação específica da competição desleal da Alemanha aparece numa lei chamada Gesetz zum Schutz der Warenzeichnung, de 1894, que regulou penalmente certos atos de confusão, por exemplo a imitação de marcas e embalagens e a falsa utilização de denominação de origens. Mais tarde, uma outra lei, a Gesetz gegen den unlauteren Wettbeweber de 24.05.1896, proíbe o anúncio enganoso nos arts. $1^{\circ}$ a $4^{\circ}$; os atos de depreciação da mercadoria de outrem, nos arts. $6^{\circ}$ e $7^{\circ}$; os atos de confusão, no art. $8^{\circ}$; a violação dos segredos das indústrias dos arts. $9^{\circ}$ e 10 .

Na Áustria, seguiu-se um curso semelhante.

11. Esta postura sobrevive no pensamento de alguns economistas modemos, ainda que com modificações e tem sido apontada como um neo-mercantilismo; nesta visão moderna a proteção deveria ter alcance apenas local, negada aos estrangeiros. 
$\mathrm{Na}$ França, buscaram-se os mesmos objetivos por outros meios. Toda a defesa da competência desleal se desenvolveu com base na jurisprudência e esta foi elaborada sobre o princípio da responsabilidade civil, contemplado no art. 1.382 do Código Civil.

Até meados do século XIX, o direito de marca era protegido por este caminho. Os tribunais, como dizia Krasser, no volume sobre a França, ${ }^{12}$ pretendiam compatibilizar a proteção da propriedade, com a extensão da liberdade de comércio e indústria.

Assim, era muito limitado o âmbito objetivo da regulamentação sobre a competência desleal. Depois, sempre a partir deste mesmo art. 1.382 do Código Napoleão, desenvolveu-se uma doutrina geral da concorrência desleal, que evoluiu até o segundo modelo de regulamentação.

Nessa evolução, verifica-se já na segunda metade do século XIX que o acento é colocado pelos tribunais não tanto na violação de um direito de propriedade industrial, quanto no aspecto doloso resultante do engano ou confusão que este contém.

Assim, o objeto da valoração deixa de ser o direito violado, para ser a conduta que causou o dano, no que coincide com a solução adotada na Alemanha.

Por aí, a jurisprudência foi se emancipando pouco a pouco da contemplação do direito violado e se encaminhou para um âmbito de discricionariedade maior, unindo sempre a repressão à deslealdade, portanto, sempre tentando julgar uma conduta.

Daí, chegou à construção de um sistema normativo sobre a competição desleal, baseado numa cláusula geral de responsabilidade extra-contratual.

Todo o tipo de confusão era punido, ainda que não tivesse por objeto a propriedade industrial, os elementos da empresa de valor competitivo, como seus ornamentos, segredos industriais, crédito industrial, reputação, marcas, denominações de origem, os quais passaram, então a ser protegidos.

$\mathrm{Na}$ Itália, a doutrina da competição desleal teve início, como na França, no seio da responsabilidade civil (art. 1.151 do Código Civil de 1865) porém, a evolução italiana, mais tardia, não deu lugar a uma disciplina geral da

12. France, in Ulmer et. al. La répression de la concurrence déloyale dans les états membres de la CEE, Paris, 1972 , p. 147 e ss. 
competição desleal, mas apenas a um caminho que protegia determinadas condutas típicas.

Os critérios valorativos da antijurisdicidade eram extraídos sempre do Direito Penal. De qualquer modo, é só em 1928, ao se dar eficácia interna ao art. 10 bis da União de Paris, que a Itália começa a ter uma disciplina geral relativa a competição desleal.

Vejamos agora o nosso paradigma, a Espanha.

O direito espanhol baseava-se em artigos do Código Penal espanhol de 1848, (art. 457); essa regra vedava e punia a violação de direitos sobre sinais distintivos. A longa série de códigos penais que se sucederam, (1850, 1870, 1928, 1932, 1944, e 1973) mantém a proteção para as marcas criadas ao abrigo do Real Decreto de 20 de dezembro de 1850, e depois da Lei da Propriedade Industrial de 1902.

Quando essa Lei foi editada não havia na Espanha uma legislação específica de repressão à concorrência desleal de caráter privado, mas apenas as leis mencionadas, de caráter rigorosamente penal.

Aliás o mesmo ocorria com a lei portuguesa, e no Brasil. Nestes países, como na Alemanha e na Áustria, a matéria é vista sob a óptica penal, ao contrário do que ocorreu na França e na Itália, onde era encarada a partir de uma plataforma civil. Esta permitia uma regra genérica de aplicação casuística, enquanto o primeiro enfoque exigia a definição precisa do tipo incriminado - nullum crimen, nulla poena sine lege.

É bem verdade que o ilícito penal pode servir de base para uma indenização. Mas o fato é que a proteção da marca - e a repressão da concorrência desleal - se faz pela via penal. A limitação da indenização aos fatos incriminados, nessa fase, era o divisor de águas entre uma cláusula geral e a proteção fragmentária e específica. $\mathrm{E}$ ao lermos os textos dos autores nacionais como os dos ibéricos vemos esse panorama, em que a idéia liberal de liberdade de concorrência ainda não havia alcançado o seu zenite, antes encontrava-se num alvorecer cinzento.

De todas as maneiras, o modelo paleo liberal evolui seguindo os passos da consolidação do liberalismo na economia internacionalmente. Ele muda, em razão da pressão de um empresariado nascente, que pedia uma proteção das posições que havia adquirido no mercado. É a origem do novo modelo que examinaremos. 


\section{O modelo profissional}

Desde o final do século XIX, e nos princípios do atual, a demanda por uma legislação que sob o prisma profissional - protegesse as posições que cada um havia conquistado no mercado. É a comunidade empresarial que passa assim a determinar as regras ${ }^{13}$ de conduta correta, e a pedir a incriminação das que vêem como desleais. É nesta fase que se pode falar corretamente de uma disciplina da concorrência desleal.

É então que surge a técnica da chamada cláusula geral. Essa passa a ser a regra dominante na disciplina da matéria, pois serviria para proteger a empresa mais além do que o permitia a sistemática do modelo profissional.

$\mathrm{O}$ interesse jurídico tutelado deixa de ser a propriedade, para ser o conjunto dos interesses da empresa em relação a outras, dentro do mercado. A introdução da noção de mercado é a grande novidade nesta mutação. Lendo a exposição de motivos da lei alemã de 1909 que serviu de paradigma para o modelo profissional vemos que para o legislador de então:

" a tutela do público consumidor não constitui o objeto de uma lei contra os atos de concorrência desleal, muito embora as regras que se destinam a reforçar a confiança recíproca nas relações entre empresários vão, indiretamente, coincidir com os interesses dos consumidores"

Os empresários então usaram sua influência para obter que a legislação concorrencial submetesse o julgamento da deslealdade a um padrão da classe (como ocorre nos processos disciplinares nas corporações profissionais do Brasil) e conseqüentemente passam a estabelecer os parâmetros que separam da concorrência lícita a ilícita.

Em suma, o ato de concorrência desleal era um ilícito profissional, uma violação às regras da deontologia, e o direito da concorrência um direito profissional.

Eis porque a tônica passa do penal para o cível, e as sanções encontram-se no âmbito do direito privado: perdas e danos, interditos proibitórios,

13. Veja-se, para um estudo mais profundo deste aspecto, a obra citada de G. Ghidini, Slealtá della concorrenza, p. 28 e ss. 
etc. A finalidade das sanções é fazer cessar a prática do ato assim como de compor os prejuízos.

$\mathrm{Na}$ Alemanha, que como vimos foi o paradigma para este modelo, a Gesetz gegen den unlauteren Wettbewerber a lei de concorrência de 1909 a que nos referimos atrás contém a mãe das cláusulas gerais:

"Quem no tráfico econômico desenvolva
comportamentos competitivos que sejam contrários aos
bons costumes pode ser demandado para que cesse os
mesmose indenize os danos causados"

A lei legitima as corporações profissionais a agirem, e tipifica algumas hipóteses de concorrência desleal.

A lei austríaca de 23 de setembro de 1923 a Bundesgesetz gegen den unlauteren Wettbewerber segue esse mesmo modelo, e ainda é inspirada nele apesar de mais evoluída - a lei suíça de 29 de setembro de 1943.

Na Itália, segue-se outro caminho, paralelo. Depois de vários fracassos legislativos, um Decreto Real de 10 de janeiro de 1926 manda aplicar o art. 10 da Convenção da União de Paris. E, depois, os arts. 2.598 e 2.599 do Código Civil de 1942 vem consolidar a idéia da cláusula geral, contida no primeiro, utilizando-se do critério da corretezza professionale, a qual é certamente medida segundo o padrão profissional. O segundo legitima as associações profissionais a agirem.

$\mathrm{Na}$ França, a evolução prossegue pela via jurisprudência, pois os tribunais desenvolvem a noção de concurrence déloyale, sempre no quadro da responsabilidade civil e ao abrigo do art. 1.382 do Código Civil.

Por isso, a legitimidade para agir era sempre do prejudicado direto, porém uma lei de 21 de março de 1894, modificada por outra de 5 de março de 1908 , legitima as ações de associações profissionais.

É a partir dessa experiência que na Europa continental se desenvolve a doutrina da concorrência desleal, firmada em alguns pontos basilares tais como a determinação do bem jurídico protegido, a identificação dos critérios identificadores da deslealdade, e o estabelecimento dos pressupostos de aplicação desse direito.

É preciso sublinhar que apesar da generalização, o fundamento continua a ser individualista, razão pela qual a doutrina segue a trilha do direito subjetivo que é lesado pelo ato de concorrência desleal. 
Essa raiz individualista faz com que a ação do Estado se deva revestir de um caráter de neutralidade passiva, isto é como mero instrumento de composição de conflitos entre empresários.

É importante ressaltar que esta postura conduz à proteção de posições conquistadas no mercado, e por conseguinte fortalece os mais fortes, levando ao monopólio (que, aliás não condena).

A cláusula geral também atua como um endereçador a parâmetros profissionais. Assim se constata ao ver que na lei alemã, fala-se de bons costumes, na italiana, de correção profissional, na lei suíça, em boa-fé objetiva, e no art. 10 da União de Paris, em usos honestos em matéria industrial e comercial. A interpretação destas expressões se faz segundo duas vertentes principais - uma baseia-se nos usos e costumes do comércio, isto é, numa visão sociológica, e outra, numa interpretação moral, pelo que foi chamada de corrente deontológica.

Por esta razão na primeira corrente predomina um enfoque mais objetivo é a conduta que interessa, a despeito das intenções e na segunda um modo de ver subjetivo onde a conduta é valorada, exigindo-se um intuito fraudulento, a má-fé, a consciência de agir deslealmente, etc.

As duas correntes têm em comum o fato de que a integração se faz com elementos estranhos à norma, e que a conduta só é ilícita quando se realize numa relação de concorrência. Esta é com efeito o pressuposto da aplicação da norma, o que leva a que vítima e delinqüente devam ser empresários, dedicados a atividades análogas.

Na Espanha, nosso paradigma, como no Brasil é pela porta da União de Paris, e de seu art. 10 que penetra a idéia de concorrência desleal e a sua repressão. Mas, lá como aqui essa norma foi de aplicação rara, e conhecimento escasso. Permaneceram vigorosas aquelas do modelo anterior.

Esse panorama segue em todo o continente europeu e na América Latina até os anos seguintes ao término da Segunda Guerra Mundial, quando sob o impacto da hegemonia dos Estados Unidos e do advento da bipolaridade, faz-se sentir a ideologia do Shermann Act.

É o advento do modelo social. 
O modelo social

É o rompimento da ligação até então existente entre o interesse do empresariado concorrente (da lealdade profissional, ou da conduta profissionalmente correta) e o interesse social, predominando este sobre aquele. Pouco a pouco, a sociedade faz sentir o seu interesse na existência da concorrência e não do resguardo de posições de mercado.

O objetivo da proteção passa a ser a tutela dos direitos dos consumidores a um mercado livre e competitivo, o que representa o interesse público.

A atuação do estado deixa de ser a da neutralidade passiva para ser a da intervenção ativa. Para isso deixa-se de medir as ações do empresário sob o prisma da incorreção da conduta face a padrões da classe empresarial, para valorá-la face aos resultados que pode produzir do ponto de vista do direito dos consumidores a um mercado competitivo e de livre acesso. Práticas que nunca tinham sido condenadas, como os preços predatórios, os cartéis, certos acordos de distribuição, vendas vinculadas etc., passam a ser incriminadas.

Nasce aí o direito antitruste. Ele tem o condão de fazer passar a livre concorrência de um "estado natural" como o via o liberalismo do século passado para uma exigência legal.

Está aí o embrião das normas de proteção ao consumidor individual, que antecederam as normas de proteção em massa do consumidor ${ }^{14} \mathrm{e}$ as regras de defesa da concorrência (e não dos concorrentes) que ocupam o espaço antes ocupado pela lei da sobrevivência do mais forte no mercado. É o nascimento do direito antitruste.

\section{O Direito Antitruste}

O capitalismo como o "conjunto de comportamentos individuais $e$ coletivos, atinentes à produção, distribuição e consumo dos bens" ${ }^{15}$ é o objeto da atuação do ramo do Direito regulador desses comportamentos.

14. Cf. Baptista, L. O., $O$ código de defesa do consumidor ...

15. Rusconi, G. E.vo. Capitalismo, in Dicionário de Política, N. Bobbio e os., p. 141. 
Com efeito, o que distingue o capitalismo de outros meios de produção conhecidos historicamente é a propriedade privada dos meios de produção "para cuja ativação é necessária a presença do trabalho assalariado formalmente livre, um sistema de mercado baseado na empresa e na iniciativa privada, individual ou coletiva, e, finalmente, processos de racionalização dos meios $e$ métodos para a exploração das oportunidades de mercado visando o lucro e o desfrute do capital, distribuídos por toda a sociedade". É esta característica, da distribuição das oportunidades, conjugada com a da liberdade econômica que fizeram com que a idéia de capitalismo se associasse com a de liberalismo ou de sistema político liberal, de modo que, na sua formulação clássica, um não se realiza sem o outro.

$\mathrm{Na}$ medida em que se falou de racionalização da economia e em assegurar a todos a possibilidade de exercer uma atividade econômica, logo surgiu a necessidade de regular os abusos. Estes decorrem da posição dominante, da vontade de viciar o mercado por práticas ditas anticoncorrenciais, como também da utilização de artifícios e fraudes na venda de mercadorias.

É, portanto, dentro da óptica do controle dos abusos à liberdade de iniciativa que toda a legislação econômica repressiva moderna veio a ser criada, interpretada e aplicada.

Entretanto mesmo nessa óptica, o percurso da regulamentação da matéria foi longo.

II - Origem da legislação de repressão dos abusos de poder econômico no Brasil

É à Constituição de 1934 que se costuma atribuir a primazia do emprego da expressão "economia popular" no Direito brasileiro. O art. 117 da chamada "Polaca" dispunha:

"A lei promoverá o fomento da economia popular, o desenvolvimento do crédito e nacionalização das companhias de seguros, em todas as modalidades, devendo constituir-se em sociedades brasileiras as estrangeiras que atualmente operam no País". 
Podemos tomar essa como o marco inicial desta retrospectiva histórica que pode ser repartida em dois períodos: o de Vargas, e o que sucedeu à Constituição de 1946.

A) Repressão dos abusos de poder econômico no Período Vargas

A Carta de 1934, inaugurava a expressão "economia popular" sob a inspiração de Francisco Campos, homem fascinado por Mussolini e pelas doutrinas do fascismo.

Este como se sabe, na órbita econômica, era a resultante da mescla de doutrinas socialistas maldigeridas, com uma visão autoritária do Estado, o que resultava num capitalismo de Estado.

Mas essa norma constitucional não chegou a produzir mais efeitos sobre a ordem jurídica brasileira e a estrutura do mercado, além da criação de mais um cartório, o das seguradoras.

Logo essa Carta é revogada, e a que lhe sucede, em 1937, dispunha o art. 141,

"A lei fomentará a economia popular, assegurando-lhe garantias especiais. Os crimes contra a economia popular são equiparados aos crimes contra o estado, devendo a lei cominar-lhes penas graves e prescreverlhes processo e julgamento adequados à sua pronta $e$ segura punição"

Campos logo regulou o dispositivo, também de sua inspiração, usando dos poderes que o cargo de Ministro da Justiça lhe dava. Foi o Decreto-lei n. 869, de 18 de novembro de 1938, conhecido depois como "lei dos crimes contra a economia popular", e a seu propósito, disse ${ }^{16}$ o Ministro signatário:

"O segundo fim da lei é evitar o bloqueio da concorrência por meio de arranjos, combinações ou organizações destinadas a estabelecer o monopólio em certos ramos da economia pública ou a restringem a 
livre competição, indispensável ao desenvolvimento industrial e comercial do País.

A economia de criação se desenvolve no mercado livre, em que o preço é determinado pelos fatores econômicos, reais, como juros ao capital invertido, mãode-obra, matéria-prima, impostos, transportes, enfim, o que se abrange com a denominação geral de custo da produção. A concorrência determina cada dia maior baixa de preço de custo e, conseqüentemente, maior expansão do consumo, do que resulta um elevamento do nivel geral de bem estar do povo.

No momento, porém, em que determinado número de empresas fortes se aliam para tomar conta do mercado, surgem as combinações, os trustes e os cartéis. Os preços passam a ser decretados por uma minoria de especuladores, cujo âmbito de ação se irradia de acordo com os lucros obtidos artificialmente, resultando daí a sujeição da imensa maioria aos seus desígnios que, dentro de pouco, ultrapassam o simples terreno econômico"

O Decreto-lei n. 869 era, porém, mais que uma lei antitruste, como se as conhecia na época. A seu propósito, doutrinava Nelson Hungria, ${ }^{17}$ autor do projeto:

"Pode dizer-se de modo geral, que o decreto lei $n$. 869 considera crime contra a economia popular todo fato que represente um dano efetivo ou potencial ao patrimônio de um indefinido número de pessoas. As entidades criminais que ele define podem ser assim classificadas:

a) monopólios;

b) artificios, fraudes e abusos contra a economia popular;

17. Dos crimes contra a economia popular, Rio de Janeiro, 1939, p. 16. 
c) usura (pecuniária e real).

As ávidas concentrações capitalistas, o arbítrio dos interesses individuais coligados, a opressão econômica, a artificial desnormalização dos preços, os lucros onzenários, o indevido enriquecimento de alguns em prejuízo do maior número, as 'arapucas' para captação do dinheiro do povo, as cláusulas leoninas nas vendas a prestações, o viciamento dos pesos e medidas e, em geral, as burlas empregadas em detrimento da bolsa popular já não poderão vingar impunemente"

Mas os tempos ainda não eram maduros para a aplicação do direito antitruste mal havia se iniciado o processo de industrialização - e por isso num só caso, ao que consta, foram os dispositivos concernentes à matéria aplicados. Foi numa consulta feita a propósito de contratos passados entre a Standard Oil Company do Brasil com proprietários de postos de gasolina, respondida por Anibal Freire, então Consultor Geral da República e aprovada por Vargas. ${ }^{18}$

Entretanto, na parte concernente ao controle de preços, supressão de fraudes e artifícios na venda de mercadorias, o decreto teve aplicação mais ampla.

Atribuiu-se à falta de um organismo especializado, nos moldes do norte-americano, a não-aplicação da norma em matéria de antitruste. ${ }^{19}$ Não creio que essa explicação seja convincente, ou pelo menos seja no todo verdadeira a verdade é que a implantação de uma economia em moldes capitalistas modernos é mais tardia, e não havia fatos a serem regulados naquela fase da história econômica.

É, em 1945, que as coisas começam a mudar, e Agamenon Magalhães, Ministro da Justiça, faz editar o Decreto-lei n. 7.666, de 22 de junho de 1945, precursor da que viria a ser a lei antitruste, fruto do projeto que o mesmo Agamenon Magalhães veio, depois, a apresentar à Câmara dos Deputados, após a Constituição de 1946.

O Decreto-lei n. 7.666-45 apresentava como inovação considerável sobre o anterior a criação do organismo de controle - chamado já de CADE, e introduzia um esboço da lei que veio depois a ser editada.

18. Diário Oficial da União, 20 de março de 1939, I, p. 6276-7.

19. Shieber, Benjamin M., Abusos do Poder Econômico, São Paulo, 1966, p. 6. 
B) Da Constituição de 1946 a nossos dias

A lei antitruste, na vida de Agamenon Magalhães, desempenhou o mesmo papel da lei do divórcio, para a de Nelson Carneiro. Essa bandeira, desfraldada em 1945, com o Decreto-lei n. 7.666, é seu estandarte na Constituinte de 46 , em cuja $7^{\mathrm{a}}$ subcomissão foi o relator da matéria sobre a ordem econômica e social. Aí teve a oportunidade de inscrever o art. 148 , justificando-o: ${ }^{20}$

"A característica da economia liberal é a livre disposição dos meios de produção. Todos os indivíduos participam desses meios, tendo liberdade de iniciativa ou de empresa. A livre concorrência é, portanto, a base da economia liberal.

Que é, então, o poder econômico? $O$ poder econômico é o que resulta da posse dos meios de produção. Quando esses meios de produção, em certos setores da atividade, são dominados por um indivíduo ou um grupo de indivíduos, são dominados por uma empresa ou por um grupo de empresas, evitando que outros deles também possam dispor, há abuso do poder econômico.

Que deve, nessa emergência, fazer o Estado, que é liberal, que tem por fundamento econômico a livre concorrência? Intervir para evitar ou suprimir o abuso.

Eis aqui a razão do art. 148 da Constituição de 18 de setembro de 1946.

Eis aqui a razão do nosso projeto que regula a repressão ao abuso do poder econômico em obediência àquele dispositivo constitucional"

Aprovada a norma constitucional, Agamenon Magalhães quis regulamentá-la, e para isso apresentou o projeto de lei 122-1948, que continha a 
semente da Lei n. 4.137, aprovada e sancionada, mais de quinze anos depois, após tumultuado curso no Congresso, que não é o caso de aqui recordar.

O Decreto-lei n. 7.666 foi revogado pelo Golpe de Estado de 29 de outubro (queda de Vargas), tendo ficado a matéria do antitruste e dos crimes contra a economia popular sem regulamentação até 1951, quando foram editadas as leis ns. 1.521 e 1.522 que estabeleciam um sistema administrativo de controle de preços, restabelecendo em matéria de antitruste o que constava no Decreto-lei n. 869 de 1938. Foram essas leis que criaram a famigerada COFAP, da qual a maioria de nós se recorda e que foi a antecessora da SUNAB e do CIP.

Com o advento da Lei n. 4.137, de 10 de setembro de 1962, passou o País a ter não só uma legislação antitruste, como também o órgão destinado a dar-lhe aplicação, o CADE. A lei teve o seu primeiro regulamento no Decreto n. 52.025, de 20 de maio de 1963.

Cabe uma palavra sobre essa norma e suas finalidades. E é sobre a matéria de sua constitucionalidade. O art. 148 da Constituição Federal de 1946 determinava que:

"A lei reprimirá toda e qualquer forma de abuso de poder econômico, inclusive as uniões ou agrupamentos de empresas individuais ou sociais, seja qual for a sua natureza, que tenham por fim dominar os mercados nacionais, eliminar a concorrência e aumentar arbitrariamente os lucros".

O problema, que nunca foi posto ao S.T.F., era o do alcance do art. 148: alguns intérpretes realçavam a expressão "toda e qualquer forma de abuso de poder econômico": aumentando a esfera do poder repressivo do Estado. A questão suscitada pelo Deputado Ulisses Guimarães, ${ }^{21}$ já quando do exame do projeto de que resultaria a Lei n. 4.137 pela Comissão de Constituição e Justiça da Câmara dos Deputados, nos seguintes termos:

"O poder econômico pode ser usado e abusado. $O$ uso não pode se degenerar em abuso. Bem como a contenção do abuso não pode se extremar na supressão

21. Parecer do Relator designado Ulisses Guimarães, da Comissão de Constituição e Justiça, de 29 de abril de 1961, Suplemento A, p. 37, D.O. 
ou limitação do uso. Seria como o remédio que a um tempo matasse a doença e o doente. Em estilo compacto, é isso o que diz o art. 148 da Constituição Federal. A linha limítrofe separando o uso do poder econômico, como um direito do seu abuso, como um crime, é o primeiro dever e a maior dificuldade do legislador incumbido de traçá-la. Esse pesado e perigoso dever, o Congresso Nacional está emprazado a cumprir neste momento.

Como se leu, o art. 148 não se circunscreveu a cuidar do abuso econômico in genere, deferindo a lei ordinária, posterior, de teor jurídico complementar, em termos casuísticos ou de análise descrever e enumerar as espécies desses abusos. $O$ art. 148 definiu uma das espécies do abuso do poder econômico, dando-lhe categoria constitucional pela sua gravidade e pela envergadura regional, senão nacional, do dano que causa. Nomeou os trustes, fazendo-o pela forma abrangente ou analítica das uniões ou agrupamentos de empresas individuais ou sociais, seja qual for sua natureza, que tenham por fim dominar os mercados nacionais, eliminar a concorrência e aumentar arbitrariamente os lucros.

No art. 154, explicita outra modalidade de abuso do poder econômico ao ordenar que a lei puna a usura em todas as modalidades".

No mesmo sentido opinou Themistocles Brandão Cavalcanti nos seus comentários à Carta de $46^{22}$ a quem ecoou Agamenon Magalhães, elaborando o seu projeto nos limites mais amplos da interpretação daquele artigo.

O Deputado Jacob Frantz exprimia a posição contrária, que resultou, em parte, vencida na Comissão de Constituição e Justiça: 
"Dentro do entendimento inflexivel do texto do art. 148, pergunto: deve a lei exigir a constatação do domínio do mercado, da eliminação da concorrência ou do aumento de lucros, para caracterizar o ato ou fato punivel, ou deve a lei fazer essa mesma exigência também para todas as outras formas genéricas de abuso a que se reporta o art. 148 ?

As minhas dúvidas fundavam-se, com razão, na circunstância de se encontrarem inseridos em todas as proposições, projeto inicial, substantivos, disposições que jamais terão por efeito o domínio dos mercados, a eliminação da concorrência ou o aumento arbitrário dos lucros, arroladas, no entanto, como formas de abuso do poder econômico.

Depois de muita meditação, cheguei à conviç̧ão de que em boa lógica e para os objetivos da lei em elaboração, não se pode desvincular aquelas três conseqüências de que fala o art. 148. Em outras palavras: os atos ou fatos dos quais não resulte o domínio dos mercados, ou a eliminação da concorrência ou o aumento arbitrário dos lucros, não podem ser arrolados como sendo abuso do poder econômico nem podem ser passíveis de punição dentro da lei que irá regular a repressão dos atos legitimamente abusivos.

... (omissis) ... Assim, aceito como certo o critério de que as uniões ou os agrupamentos de empresas, ou quaisquer outros atos ou fatos somente passam a ser infringentes da lei quando deles resulte, inquestionavelmente, o domínio dos mercados, a eliminação da concorrência ou o aumento arbitrário dos lucros". ${ }^{23}$ 
e Pontes de Miranda exprimiu posição idêntica no seu comentário àquela Constituição. ${ }^{24}$

Com efeito, a Lei n. 4.137 enquadra-se nos limites daquela Constituição salvo quanto ao art. $5^{\circ}$, que pune "a empresa que, operando em condições monopolísticas, interromper ou reduzir em grande escala sua produção sem justa causa ... para provocar ... a paralisação de indústrias que dela dependam". Realmente parecia difícil encontrar a conexão entre este dispositivo e os bens jurídicos tutelados, referidos no art. 148 da Carta de 46. A abusividade do ato sob o ponto de vista econômico parece evidente, mas, sob a óptica constitucional ficou duvidosa a conexão.

O exemplo serve para mostrar a dificuldade de que se reveste a matéria e o fato de que a constitucionalidade da Lei n. 4.137, embora não extreme de dúvidas nunca foi argüida de modo sério e consistente. Esse fato, por si só, serve para demonstrar que o CADE foi inócuo ou inoperante.

Hoje, a realidade é outra. Após uma série de medidas legislativas, temos uma nova lei.

São Paulo, março de 1996.

24. Comentários à Constituição de 1946, 3ª ed., t. V, 1960, p. 501. 